$\begin{gathered}\text { Науковий вісник НЛТУ України } \\ \text { Scientific Bulletin of UNFU } \\ \text { https://nv.nltu.edu.ua }\end{gathered}$
$\begin{gathered}\text { https://doi.org/10.36930/40300210 } \\ \text { Article received } 15.05 .2020 \mathrm{p} .\end{gathered}$
ISSN 2519-2477 (online)
Article accepted $04.06 .2020 \mathrm{p}$.

У. Б. Башуцька

Національний лісотехнічний університет України, м. Львів, Украйна

\title{
ЗНАЧЕННЯ ЛАНДШАФТІВ ПІСЛЯ ДОБУВАННЯ БУРОГО ВУГІЛЛЯ У СХІДНІЙ ТА ЦЕНТРАЛЬНІЙ НІМЕЧЧИНІ ДЛЯ ОХОРОНИ ПРИРОДИ
}

\begin{abstract}
Досліджено зміни ландшафту після видобування бурого вугілля у Східній та Центральній Німеччині. Проаналізовано природні сукцесії рослинних і тваринних угруповань на ділянках, які залишалися без антропогенного втручання впродовж десятиліть внаслідок відставання темпів рекультивації від темпів вугледобування за часів НДР. Зараз більшість територій $\epsilon$ рекультивованими, а деякі райони збережені для охорони природи. Процеси грунтоутворення в надмірно теплих, сухих та кислих едафотопах не змінюються довгий час. Ситуація у мокрих і затоплених місцезростаннях $\epsilon$ аналогічною. Упродовж тривалого часу в них формуються стійкі біотопи для видів рослин і тварин, які стали рідкісними на культурних ландшафтах. Динаміку природної сукцесії визначають чинники місцезростання. Ними є водний баланс (від сухого до вологого), хімічні властивості грунту (кислотність, вміст поживних і фітотоксичних речовин), а також теплова ситуація місцезростання. Описано різноманіття типів біотопів та рослинності. Показано сукцесії рослинності на кислих відвальних субстратах стосовно зволоження на підставі досліджень [3]. Обгрунтовано необхідність здійснення заходів із охорони навколишнього середовища та небезпеку порушення його цілісності та якості внаслідок здійснення гірничих робіт. Важливою $є$ охорона неживої природи і ландшафту, як основа охорони флори і фауни. Цифри демонструють велике значення ландшафтів після добування бурого вугілля для біорізноманіття та охорони видів у Німеччині. Причинами успіху є різноманітність структур, великі площі та відносно низький рівень антропогенного втручання у колишні буровугільні розробки відкритого типу. Ці фактори були втрачені на більшій частині культурного ландшафту. Під час здійснення регулювання сукцесії потрібно застосовувати підходи, максимально наближені до природних. Населенню необхідно забезпечувати доступ до таких територій для набуття нового досвіду і відчуття природи.
\end{abstract}

Ключові слова: буре вугілля; післягірничі ландшафти; рекультиваційні роботи; біорізноманіття; екотоп; природна сукцесія; охорона природи.

Вступ. Антропогенний ландшафт - це різні форми прояву людської діяльності в ландшафті. Їх поділяють на дві групи: типи використання земель чи угіддя (пасовища, плантації, сади); інженерні комплекси (мало- та багатоповерхові споруди чи цілі міста, дороги). Від того, яке до кожного з них додають слово ландшафт, тобто перейменовують населені пункти в системні ландшафти, чи називають поле соняхів соняховим ландшафтом, ні наука ні практика нічого не виграють.

Не на користь йдуть і пропозиції відмовитися від загальноприйнятих назв ландшафтних зон (лісостеп, степ) і віднині вважати степову зону польовою, лісостепову - пасовищною. Також пропонують передати вивчення природних зон палеогеографії, ніби в зоні мусонних тропіків через вирубування лісів припинилася мусонна циркуляція атмосфери, змінився потік сонячної радіації, зник характерний режим зволоження чи стерлися 3 лиця землі гірські хребти з їх висотними поясами.

Антропогенна трансформація ландшафту - зміна природних систем під впливом господарської діяльності людини. Це інтегрована характеристика, яка враховуе не тільки зміни структури геосистеми загалом, але й фізичні й хімічні забруднення компонентів ландшафтної системи, зміни ії видового складу. Антропогенна трансформація характеризує сукупний впливів різних видів навантажень на ландшафтну систему загалом. Це результат взаємодії людини 3 довкіллям у межах конкретних геосистем.

Гірничопромисловий ландшафт вирізняється створенням разом із виробничими спорудами систем збагачення, очищення та складування відходів із відповідною інфраструктурою гірничо-збагачувальних комбінатів (ГЗК), кар'єрів, шахт, будівництвом терасованих воронок, виникненням озер. Техногенні від'ємні форми рельєфу чергуються з позитивними - відвалами, териконами, насипами. При цьому змінюються рослинний покрив та склад грунтів. Такі ландшафти формуються за відносно короткий проміжок часу, займаючи великі території. Особливо це стосується полігонів відходів від вугільних шахт, залізорудних кар'єрів, родовищ кам'яної солі, глин, пісків та ін.

Порушені добуванням бурого вугілля ландшафти займають значні території у Східній та Центральній Нiмеччині. Видобуток бурого вугілля в Лаузіц навколо міст Хойерсверда, Лаухаммер, Сенфтенберг, Котбус і Вайсвассер (рис. 1), а також у районі Центральної Нi-

Інформація про авторів:

Башуцька Уляна Богданівна, канд. с.-г. наук, доцент, кафедра екології.

Email: ecology@nltu.edu.ua; https://orcid.org/0000-0002-4131-014X

Цитування за ДСтУ: Башуцька У. Б. Значення ландшафтів після добування бурого вугілля у Східній та Центральній Німеччині для охорони природи. Науковий вісник НЛТУ України. 2020, т. 30, № 2. С. 55-61.

Citation APA: Bashutska, U. В. (2020). Importance of landscape after brown coal mining in Eastern and Central Germany for the nature protection. Scientific Bulletin of UNFU, 30(2), 55-61. https://doi.org/10.36930/40300210 
меччини $з$ центрами Цайц-Вайсенфельс, Борна-Лейпциг і область Галенсер-Біттерфельд (рис. 2) відбувається у промисловому масштабі понад 200 років [5].

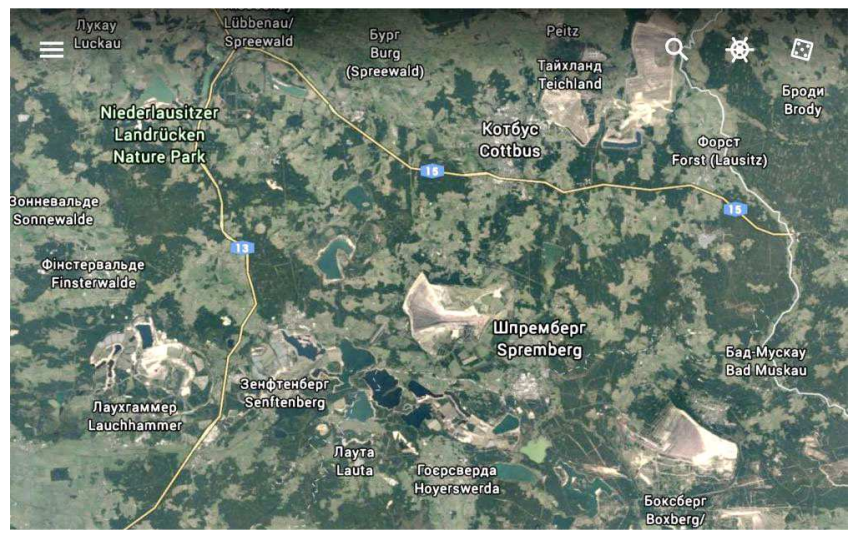

Рис. 1. Післягірничі ландшафти Східної Німеччини (Geobasis$\mathrm{DE} / \mathrm{BKG})$

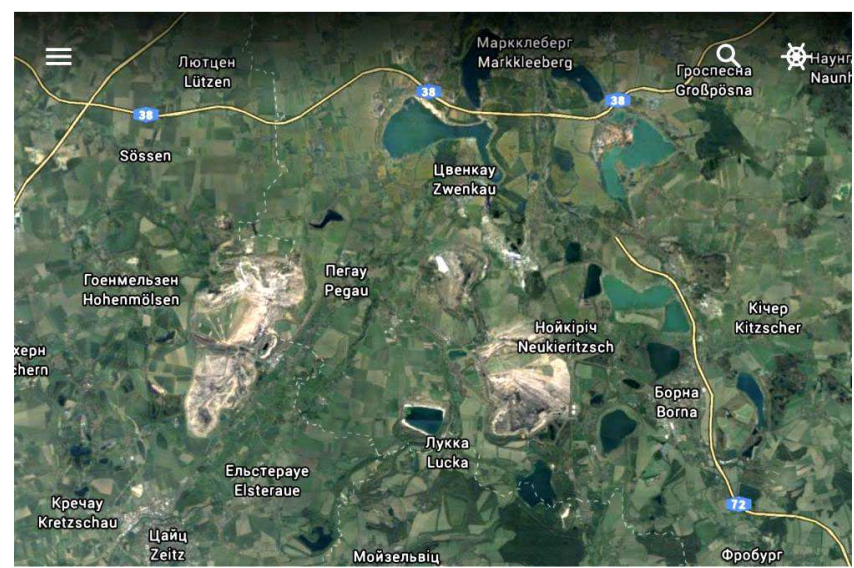

Рис. 2. Післягірничі ландшафти Центральної Німеччини (Geobasis-DE/BKG)

Розвиток грунту відбувається повільними темпами навіть через кілька десятиліть після припинення відсипання відвалів. Процес грунтоутворення є обмежений відсутністю верхнього гумусовмісного шару грунту. Відвальні породи містять в надлишку мінерали із високим вмістом сірки. Їх вивітрювання відбувається з утворенням сірчаної кислоти. Із відвальних порід високої кислотності формуються грунти, які мають низький вміст поживних речовин. Негативним чинником грунтоутворення також $є$ надмірне ущільнення відвальних порід робочими машинами. Відсипний матеріал часто розташовується на поверхні неоднорідно, створюючи мозаїчний ландшафт із багатьма екологічними нішами. Такі екотопи створюють багато можливостей спеціалізованим видам рослин і тварин $[1,2,3,4,5]$.

Об'єкт дослідження - новоутворені середовища існування порушених добуванням бурого вугілля ландшафтів у Східній Німеччині.

Предмет дослідження - видове різноманіття та сукцесійні процеси на післягірничих ландшафтах.

Мета дослідження - проаналізувати фактичну інформацію про особливості екотопів, розвиток біорізноманіття та її важливість для охорони природи під час здійснення планових рекультиваційних робіт на післягірничих територіях.

Завдання дослідження полягає в отриманні даних про новостворені середовища існування, видове різноманіття екотопів та їх особливе природоохоронне значення для довкілля.
Новизна отриманих матеріалів полягає в тому, що вперше на підставі вивчення комплексного аналізу робіт про різноманіття екотопів та сукцесій рослинних і тваринних угруповань ландшафтів після добування бурого вугілля у Східній та Центральній Німеччині показано їх великі можливості для збереження біорізноманіття.

Практична значущість результатів дослідження полягає у тому, що вони можуть бути використані у практиці планування рекультиваційних робіт на післягірничих ландшафтах України для забезпечення охорони природи, а також раціонального користування ресурсами післягірничих ландшафтів на засадах, максимально наближених до природних.

Актуальність дослідження полягає у розширенні знань стосовно можливостей охорони природи на післягірничих ландшафтах для оптимального планування рекультиваційних заходів.

Аналіз літературних джерел. Під час використання затверджених запасів на територіях Лаузіц та Центральної Німеччини планують гірничі роботи на території,

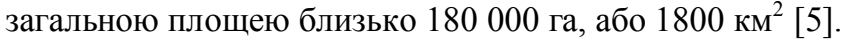
Найвищий рівень добування бурого вугілля був у період 1950-1990 pр., що супроводжувалося утворенням у цей часовий проміжок найбільшої площі порушених земель [2]. На початку промислового добування буре вугілля залягало дуже близько до поверхні. Сьогодні для його добування потрібно видалити шар гірських порід потужністю до 120 м. Відсипка цих мас почалася 3 1920-х років і здійснювалася переважно транспортерновідвальними мостами та великими стрічковими транспортерами [5]. Унаслідок цього утворилися змішані системи субстратів із плейстоценових і піритвмісних третинних пісків та суглинків 3 різним вмістом вугілля. Вони є початковими матеріалами для грунтоутворення i зумовлюють формування на поверхні відвалів фрагментів із змінними властивостями [1]. У часи НДР темпи рекультивації були нижчими, ніж швидкість виникнення нових порушених земель [2]. Території під нерекультивованими відвалами стали переважати на десятках тисяч гектарів. Природні процеси розвитку відбувалися на них протягом 40 років без втручання людини [3, 4]. 3 різким припиненням виробництва у 1990-1992 рр. на діючих відкритих шахтах до порушених земель додалися геотехнічно нестабільні та нерекультивовані схили й насипи [2].

Після політичних змін у ФРН вирішено рекультивувати порушені землі та виділити їх для охорони природи. Рекультиваційні роботи здійснювали на підставі класифікаційної системи субстратів та матеріалів картографування екотопів $[1,2,3,4,5]$. Базова концепція для розроблення меліоративних заходів лісогосподарського, сільськогосподарського чи водогосподарського напрямів рекультивації є адаптованою до кожної конкретної ділянки. Якщо фізичні і хімічні властивості відвальних порід були придатними для стійкого розвитку родючого грунту і вирощування продуктів харчування, кормових та біоенергетичних ресурсів, перевагу надавали сільськогосподарській рекультивації з метою раціонального використання земельних ресурсів. Затоплені колишні ями після добування бурого вугілля стали озерами і вже тривалий час $є$ частиною культурного ландшафту. Деякі території $є$ залісненими. Їх використову- 
ють для рекреації, а також надають в оренду для полювання за невисокими тарифами.

Природоохоронні асоціації та фонди перейняли порушені землі у власність і використовують їх для сприяння процесам природної сукцесії [2]. Ці райони мають особливе значення для сьогоднішнього різноманіття видів і середовищ існування [2, 3, 4, 5].

Матеріали і методи дослідження полягали в аналітичному опрацюванні матеріалів досліджень науковців та природоохоронної документації двох гірничих компаній. Спеціалісти гірничої компанії Лаузіц й Центральної Німеччини у документах систематизували, оцінили та зафіксували середовища існування видів та природну сукцесію рослинності. До картографування залучалися вузькоспеціалізовані науковці (орнітологи, ентомологи та ін.). Зібрано дані у державних установах та наукові роботи. На цій основі сформовано широкі бази даних для 29 різних груп видів та здійснено детальне й вичерпне картографування ландшафтів після добування бурого вугілля [2].

Результати дослідження та їх обговорення. Властивості місцезростання визначають хід природної сукцесії [4]. Відвальні субстрати, які є вихідним матеріалом для грунтоутворення, мають такі властивості:

1) осади, які переважно бідні поживними речовинами;

2) субстрати без перегною та рослинних решток;

3) немає грунтових організмів і насінних банків рослин;

4) невеликі ділянки неоднорідних субстратів змінної послідовності із вмістом сірчаної кислоти від низького до високого;

5) у водному балансі є сильні градієнти, дуже сухі поверхні чергуються з вологими та надмірно зволоженими поверхнями;

6) сухі ділянки мають тенденцію до перегрівання, внаслідок чого змінюється мікроклімат.

На екологічному рівні ландшафту виділяються такі чинники:

1) поверхні, порушені видобутком бурого вугілля відкритим способом, $є$ великими, нерозчленованим та із відносно низьким ступенем антропогенного втручання;

2) для них характерне велике різноманіття лісорослинних умов та екологічних ніш;

3) у процесах геоморфологічного та біологічного розвитку спостерігається висока динаміка [2].

Добування бурого вугілля поверхневим способом спричиняє руйнування поверхні землі через масивне втручання в ландшафт. Відбувається руйнування історично складених видів землекористування, мереж харчових ланцюгів та взаємовідносин рослин і тварин, а також природних процесів у ландшафтах. Затребувані людиною функції ландшафту, включаючи екосистемні послуги, докорінно трансформуються. Видобуток бурого вугілля в Німеччині здійснюють в інтенсивно використовуваних культурних ландшафтах $[2,3,4,5]$. Післягірничі ландшафти є новими екотопами для рослин i тварин, якщо вони залишаться територіями без інтенсивного та регулярного використання. Рекультивовані ділянки видобутку бурого вугілля сприяють підвищенню біорізноманіття післягірничих ландшафтів.

Відпрацьовані ділянки із добування бурого вугілля відкритим способом можуть розвиватися значною мірою без впливу людей або залучатися до подальшого використання шляхом цілеспрямованих рекультива- ційних заходів [2, 3, 5]. Повністю неконтрольований розвиток післягірничих територій у європейських гірничодобувних районах не є можливим, оскільки це суперечить природоохоронному законодавству. У Німеччині відпрацьовані кар'єри після добування бурого вугілля підпадають під дію Федерального закону про видобуток, який зобов'язує усунути небезпеку для громадськості та важливих ресурсів, таких як вода. Відповідальним є гірничодобувне підприємство [2].

Цілеспрямована рекультивація враховує грунтові та поверхневі води, ерозійний осад на поверхні, формування рослинного покриву, доступність територій за допомогою доріг, обладнання для пожежогасіння, охорону природи та відпочинок. Ці заходи спрямовують сукцесійний розвиток, залишаючи місце для природних процесів [3, 4]. Сукцесії рослинності на кислих відвальних субстратах залежать від водного балансу і зумовлюють формування різних лісових угруповань, за винятком акваторій та екстремальних місцезростань (таблиця).

Природна сукцесія рослинності на кислих ділянках різного ступеня зволоження зазвичай закінчується різними типами лісу. У сухих до свіжих місцезростань послідовність сукцесії характеризується різноманіттям, тоді як на дуже сухих кислих грунтах після окиснення верхнього шару грунту та певного розвитку едафотопу відносно швидко розвиваються стабільні піонерні соснові ліси. Вони можуть існувати тривалий період. В екстремальних місцях, які є дуже теплими, сухими та кислими, початкові грунти можуть довгий час не змінюватися. Аналогічною є ситуація із мокрими до затоплених місцезростань. Упродовж тривалого часу в них формуються стійкі середовища існування видів тварин, які стали рідкісними на культурних ландшафтах. Динаміку сукцесії визначають декілька чинників місцезростання. Окрім залежності від водного балансу (від сухого до вологого), це також хімічні властивості грунту (кислотність, наявність чи відсутність поживних речовин або фітотоксичних речовин), а також теплова ситуація місцезростання [2].

Відповідно до цих чинників сукцесія рослинності відбувається по-різному і впливає на різноманіття біотопів. Кількість біотопів відкритих середовищ існування, які не розташовані в екстремальних місцезростаннях, за останні 15 років значно зменшилася. Причина полягає в тому, що майже всі місцезростання гірничодобувних ландшафтів є потенційними лісовими. Злакові або трав'яні луки можуть існувати на девастованих ландшафтах лише в разі здійснення регулярних заходів 3 догляду. Стійкі луки впродовж декількох десятиліть може формувати лише небажаний із господарської точки зору злак Calamagrostis epigejos (L.) Roth. Куничник наземний $є$ найпоширенішим видом рослин у післягірничих ландшафтах. Широка екологічна амплітуда та дуже ефективна життєва стратегія дають йому змогу з'являтися у всіх наземних біотопах [4]. Отже, на постіндустріальних територіях обох регіонів добування бурого вугілля відкритим способом у найближчі роки продовжуватиме зростати кількість заплавних очеретяних угруповань на водоймах i піонерних лісів на наземних територіях. Фактично незмінені і мало змінені мозаїчні відвальні субстрати в довготерміновій перспективі можна знайти лише в екстремальних місцезростаннях. 
Незважаючи на хід сукцесії у напрямку до більш розвинених типів рослинності, флористичне різноманіття змінилося незначно. Більшість видів, зафіксованих у первинному картографуванні двадцять років тому, знайдено в наступному картографуванні в районі Центральної Німеччини. Частка видів, які зникли, компенсується нововиявленими видами. Зміна частин поверхні біотопів спричиняє збільшення або зменшення кількості видів, характерних для відповідного типу біотопу. Із ходом процесу сукцесії рослинності розвиваються також грунти. Збагачення біологічним вуглецем та біологічно зв'язаними поживними речовинами у вигляді коренів, перегною, підстилки та грунтових організмів також сприяє розвитку циклів поживних речовин у грунті [2].

Таблиця. Сукцесії рослинності на кислих відвальних субстратах (рН 3-5) стосовно зволоження [3]

\begin{tabular}{|c|c|c|c|c|}
\hline \multirow{2}{*}{$\begin{array}{l}\text { Час, } \\
\text { роки }\end{array}$} & \multicolumn{4}{|c|}{ Місцезростання за зволоженням } \\
\hline & дуже сухі (+ дуже кислі) & сухі до свіжих & (змінні-) вологі до мокрих & незначно до сильно затоплених \\
\hline $0-20$ & $\begin{array}{c}\text { мертвий субстрат - піонерні } \\
\text { псамофільні злакові } \\
\text { угруповання }\end{array}$ & $\begin{array}{c}\text { недовговічні (рудеральні) луки } \\
\text { із піонерних видів - діаспори } \\
\text { насінин (луки куничника, луки } \\
\text { багаторічних злаків і різнот- } \\
\text { рав'я, чагарники з березою) }\end{array}$ & $\begin{array}{c}\text { вологі піонерні луки - злако- } \\
\text { во-різнотравні луки вологих } \\
\text { місць - березово-вербові ча- } \\
\text { гарникові угруповання - } \\
\text { очеретяні угруповання } \\
\end{array}$ & $\begin{array}{c}\text { піонерні луки із ситником -сит- } \\
\text { никові угруповання - початкові } \\
\text { нижні болота із пухівкою - зап- } \\
\text { лавні очеретяні угруповання }\end{array}$ \\
\hline $20-40$ & $\begin{array}{c}\text { піонерні псамофільні злакові } \\
\text { угруповання - багатовидові } \\
\text { псамофільні оліготрофні зла- } \\
\text { кові угруповання - початкові } \\
\text { псамофільні чагарничкові уг- } \\
\text { руповання }\end{array}$ & \begin{tabular}{|c|} 
діаспори насінин (луки кунич- \\
ника, луки багаторічних злаків і \\
різнотрав'я, чагарники \\
з березою) \\
\end{tabular} & \begin{tabular}{|c|} 
злаково-різнотравні луки во- \\
логих місць - березово-вер- \\
бові чагарникові угрупован- \\
ня - очеретяні угруповання
\end{tabular} & $\begin{array}{c}\text { ситникові угруповання - почат- } \\
\text { кові нижні болота із пухівкою - } \\
\text { осокові угруповання - заплавні } \\
\text { очеретяні угруповання }\end{array}$ \\
\hline $40-60$ & $\begin{array}{c}\text { початкові псамофільні чагар- } \\
\text { ничкові угруповання - сукце- } \\
\text { сія сосен із жарнівцем віни- } \\
\text { ковим - сукцесія сосен }\end{array}$ & $\begin{array}{c}\text { діаспори насінин (луки кунич- } \\
\text { ника, луки багаторічних злаків і } \\
\text { різнотрав'я, чагарники з бере- } \\
\text { зою) - березові піонерні ліси }\end{array}$ & $\begin{array}{c}\text { очеретяні угруповання - вер } \\
\text { бові чагарники - березово- } \\
\text { вербові вологі ліси (верба } \\
\text { попеляста, крушина ламка) }\end{array}$ & $\begin{array}{c}\text { початкові нижні болота із пухів- } \\
\text { кою (рівномірний рівень води з } \\
\text { низьким вмістом поживних ре- } \\
\text { човин, можливо з регулюван- } \\
\text { ням) - осокові угруповання - } \\
\text { заплавні очеретяні угруповання }\end{array}$ \\
\hline $60-100$ & $\begin{array}{c}\text { сукцесія сосен - піонерні } \\
\text { соснові ліси }\end{array}$ & $\begin{array}{c}\text { березові піонерні ліси - березо- } \\
\text { во-соснові ліси із поодинокими } \\
\text { дубами - березові ліси із доміш- } \\
\text { кою дуба }\end{array}$ & $\begin{array}{c}\text { вербові чагарники - березо- } \\
\text { во-вербові вологі ліси (верба } \\
\text { попеляста, крушина ламка) }\end{array}$ & $\begin{array}{c}\text { початкові нижні болота із пухів- } \\
\text { кою (рівномірний рівень води з } \\
\text { низьким вмістом поживних ре- } \\
\text { човин, можливо з регулюван- } \\
\text { ням) - осокові угруповання - } \\
\text { заплавні очеретяні угруповання } \\
\end{array}$ \\
\hline $\begin{array}{l}100- \\
300\end{array}$ & $\begin{array}{c}\text { сосново-березові-(піонери)- } \\
\text { ліси }\end{array}$ & $\begin{array}{c}\text { березові ліси із домішкою ду- } \\
\text { ба - проміжні дубові ліси на } \\
\text { кислих грунтах - із буком } \\
\text { (діаспори насінин) }\end{array}$ & $\begin{array}{c}\text { вербові чагарники - березо- } \\
\text { во-вербові вологі ліси (верба } \\
\text { попеляста, крушина ламка)- } \\
\text { болотні ліси }\end{array}$ & \begin{tabular}{|c|} 
початкові нижні болота із пухів- \\
кою (рівномірний рівень води з \\
низьким вмістом поживних ре- \\
човин, можливо з регулюван- \\
ням) - осокові угруповання - \\
заплавні очеретяні угруповання
\end{tabular} \\
\hline
\end{tabular}

На відміну від багатьох видів рослин, переселення важливих для розвитку грунту груп тварин (дощові черв'яки), відбувається дуже повільно [3]. Вони мають низьку швидкість поширення і потребують допомоги людини. Поширенню можна сприяти за допомогою активних заходів, таких як переміщення лісового грунту, створення валів 3 пнів та мертвого дерева. Тварини потрапляють до районів рекультивації опосередковано, переміщуючись із використовуваним матеріалом і технікою.

Існує три принципово різних типи рослинності:

1) Виключно водні середовища існування, які можна розділити на а) водній поверхні та б) внизу, класифіковані за рівнями глибини.

2) Наземні середовища існування, пов'язані з водою. Сюди входять: а) джерела та схилові водостоки; б) заплавні очеретяні угруповання на берегах озер; в) наземні очеретяні угруповання, що супроводжують біотопи джерел і схилових водостоків, а також мокрі до змінної вологості місцезростання; г) осокові угруповання в мулових зонах озер; д) початкові стадії низових боліт і боліт, як дуже рідкісних видів біотопів; е) вологі луки, особливо цінними є вологі луки, багаті орхідеями.

3) Наземні середовища існування. Вони, як і водні зони, визначають характер ландшафтів після гірничих робіт. До них належать: а) місця, що містять виходи солі, як рідкісні випадки вираження на відвалах сольових вугільних пластів та золовідвалів електростанцій, що працюють на бурому вугіллі; б) вільні від рослинності та бідні на рослинність відвальні грунти; в) обриви та стрімкі схили; г) піонерні псамофільні луки в сухих місцях, далеких від грунтових вод; д) суха псамофільна злакова рослинність, як типова картина початкової сукцесії, особливо на відвалах Лаузіц; е) низькорослі вересові угруповання; ж) оліготрофні початкові злакові угруповання на вапняках лише в районі Центральної Нiмеччини; з) злаково-різнотравні луки, вони займають внаслідок рекультивації значну частину площі; і) куничникові луки, причому Calamagrostis epigejos $€$ домінуючим і найпоширенішим видом у постгірничих ландшафтах; i) мозаїчні середовища існування різноманітної рослинності; ї) чагарникові стадії місцевих видів $€$ широко поширеними; к) чагарникові стадії чужорідних видів, які часто були посаджені в рамках попередніх заходів рекультивації; м) піонерні ліси від мезотрофних до мегатрофних місцезростань; н) піонерні ліси в екстремальних місцях, таких як поверхнево окислений третинний грунтовий матеріал, місцях 3 високим вмістом вуглецю (вміст вугілля> 10-40\%), дуже стрімкі схили та насипи з високим вмістом глини; о) піонерні ліси, поперемінно вологі до мокрих місцезростань, які знаходяться під впливом підземних вод; р) проміжні 
ліси, це ліси віком від 60-100 років; с) ліси місцевих порід дерев, т) ліси чужорідних порід дерев [2].

На підставі аналізу сукцесійних процесів зроблено такі висновки:

1) Велика кількість типів рослинності виникла на місцях, що утворилися внаслідок добування бурого вугілля відкритим способом. Це відображає різні геологічні та природні умови, в яких відбулося масштабне втручання. Структура рослинності в районах Центральної Нiмеччини та Лаузіц загалом $є$ схожою, незважаючи на різний видовий склад в окремих випадках і різні домінуючі геологічні відкладення.

2) Існують численні типи рослинності (різні типи лісів, злаково-різнотравні луки та куничникові луки), які не трапляються в ландшафті, не використовуваному для видобутку бурого вугілля.

3) Існують також типи рослинності, які в "нормальному" ландшафті стали дуже рідкісними або взагалі не трапляються, наприклад, піонерні ліси на субстраті, що містить багато вуглецю $[2,4]$.

Різноманіття місцезростань навіть в найменших просторах впливає на кількість видів рослин, їх частоту трапляння, ріст і розвиток в післягірничому ландшафті (рис. 3, 4).

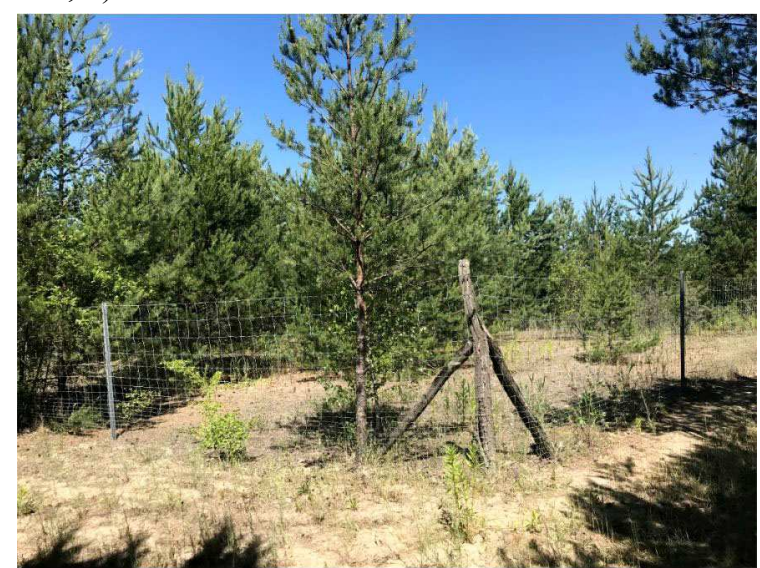

Рис. 3. Соснове угруповання рекультивованої ділянки буровугільного кар'єру

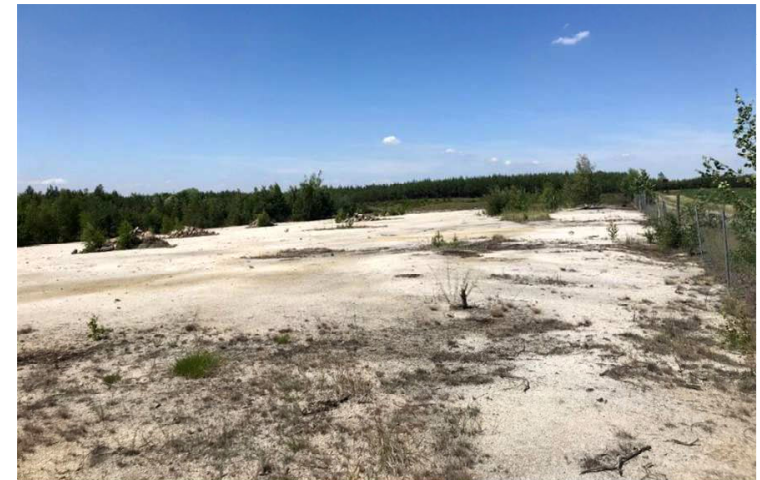

Рис. 4. Повільна сукцесія рослинності нерекультивованої ділянки буровугільного кар'єру

Для встановлення біорізноманіття автори $[1,2,3,4$, 5] вивчали середовище існування видів на площі близь-

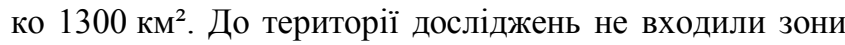
експлуатації діючих шахт відкритого добування вугілля та райони їх майбутніх гірничих районів. Площа території досліджень відповідає 0,37 \% площі земель у Німеччині. Співвідношення видів, виявлених на порушених землях, до загальної кількості видів їх кожної групи у Німеччині виявилося дуже високим. У Німеччині відомо 4165 судинних рослин. 1300 видів 3 них були знайдені на порушених ландшафтах. Це відповідає частці $31 \%$. Із 105 видів ссавців, характерних для Німеччини, на порушених ландшафтах трапляється 51 вид. На порушених землях можна знайти 5 видів із 13 видів місцевих плазунів та 15 видів із 22 видів земноводних, характерних для Німеччини. 145 видів птахів розмножуються на порушених ландшафтах. Це майже кожен другий місцевий вид у Німеччині. Порушені ландшафти є особливим і дуже важливим середовищем існування павуків, коників, цикад, жуків, метеликів і бджіл. Види, пов'язані з водним середовищем існування, такі як водяні клопи, також знаходять важливі для них екологічні ніші у ландшафтах після гірничих робіт. Зі 69 видів, що трапляються в Німеччині, 43 зараз живуть у порушених ландшафтах Лаузіц та Центральної Німеччини. Інтенсивність обліку, рівень знань про окремі видові групи і шляхи їх виникнення у порушеному ландшафті є неповними. Це стосується водних жуків, метеликів і цикад, встановлені кількості яких є заниженими [2].

Види тварин, які $є$ проблематичними у культурному ландшафті через їх комплексний захисний статус (наприклад, прудка ящірка - Lacerta agilis) або через спосіб їх життя (вовк-Canis lupus, бобер-Castor fiber), знайшли на порушених землях екологічні ніші із нижчим рівнем конфлікту.

Заселення порушеного ландшафту залежить від різних стратегій видів. Флора порушених земель має чіткий зв'язок з видами довкільних рослин.

Прудка ящірка є одним із характерних видів порушених ландшафтів, хоча в інших місцях вона трапляється не часто (рис. 5). Сприятливими для неї є теплі місця та можливість використовувати відкриті простори, які межують із краями кущів. Заселення відбувається уздовж лінійних конструкцій, таких як смуги дерев або живоплоту. 3 прогресивною сукцесією рослинності на порушених ландшафтах можна очікувати зниження щільності прудкої ящірки в довготерміновій перспективі [2, 3].

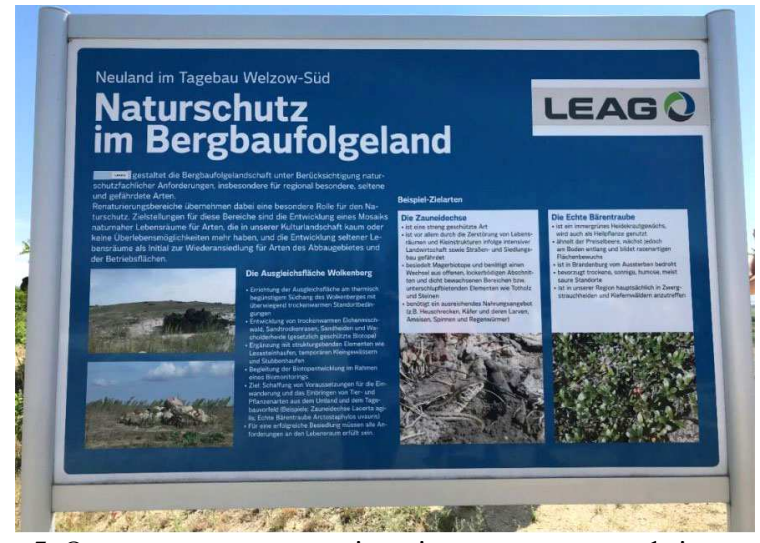

Рис. 5. Охорона природи на післягірничому ландшафті

На території колишніх буровугільних кар'єрів виявлено 44 види коників, більшість 3 яких теплолюбні. Такий вид, як пустельниця блакитнокрила (Sphingonotus caerulans) $є$ піонерним. Вона може пролітати значні відстані, зокрема перетинати лісові ділянки. Пустельниця блакитнокрила використовує гірничі породи та бідну рослинність піщаних субстратів, тому порушені ландшафти мають для неї велике значення. 3 прогресивним розвитком рослинності кількість цього виду місцями 
зменшилася. Італійський коник (Calliptamus italicus) також зміг поширитися в районі Лаузіц. Раніше йому загрожувало вимирання у Бранденбурзі і тільки переселення на порушені ландшафти забезпечило виживання. Сьогодні це є поширений вид піонерних фітоценозів, а також різнотравних і сухих злакових луків. Поселення лісового цвіркуна (Nemobius sylvestris), який є нелетучим видом, відбулося іншим способом. Його міграція із навколишніх територій відбулася лише тоді, коли на порушених землях з'явилися перші лісові фітоценози. В інші місця (наприклад, на ізольований відвал Шипкау) він прибув як "нелегальний пасажир" [2].

Цифри демонструють велике значення ландшафтів після добування бурого вугілля для біорізноманіття та охорони видів у Німеччині. Причинами широкого різноманіття видів $є$ різноманітність структур, великі площі та відносно низький рівень антропогенного втручання у колишні буровугільні розробки відкритого типу. Саме ці фактори були втрачені на більшій частині культурного ландшафту.

Післягірничі ландшафти утворюють нові біотопи, важливі для охорони природи та біорізноманіття. Вони $\epsilon$ певною заміною втрат, які відбулися в культурних ландшафтах. Великі площі післягірничих ландшафтів повинні залишатися без господарського використання та інтенсивного втручання людини.

У Німеччині сприяють відповідним організаціям брати такі території у власність для забезпечення підтримки біорізноманіття у довготерміновій перспективі. Рекультивація земель завжди повинна забезпечувати простір для природної сукцесії. У планах діючих гірничих компаній під час організації робіт потрібно завчасно враховувати високомінералізовані грунтові ділянки, ділянки сукцесії, ділянки для тимчасового нагромадження води та облаштовувати їх відповідно. Під час рекультивації порушених ландшафтів доцільно зберігати дрібномасштабні структури, а також шахтні залишки, які не завдають шкоди навколишньому середовищу. Дозволяються геотехнічно безпроблемні зміни на схилах та берегах. Для підтримання певних типів біотопів, наприклад, сприятливих для поселення відкритих земельних ділянок, повинні бути створені на ранньому етапі плани управління і забезпечені відповідні ресурси. У разі необхідності догляду варто застосовувати методи, які найкраще відповідають різним видам.

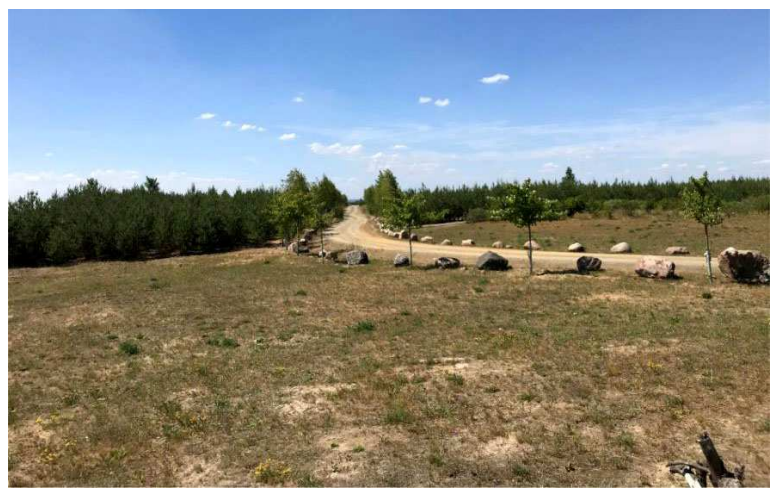

Рис. 6. Рекультивована територія буровугільного кар'єру Вельцов-Зюд
Перспективним підходом, що має приклади практичного застосування, є створення на порушених ландшафтах "диких пасовищ". На них цілорічно є невеликі, адаптовані стада великих травоїдних тварин (невибаглива худоба або коні). Тривалий моніторинг на ділянках, створених $з$ цією метою, дає змогу отримати дані, що є актуальними за межами гірничих районів. До післягірничих ландшафтів є численні вимоги використання (сільського та лісового господарств, туризму), а також виділяються ділянки для охорони природи $[2,3,4$, 5]. При цьому враховується, що населенню потрібно набувати досвід в стосунку природи. Для цього повинна бути забезпечена доступність ділянок (рис. 6).

Висновки. Внаслідок проведеного дослідження було проаналіовано фактичну інформацію про особливості екотопів, розвиток біорізноманіття та іiі важливість для охорони природи під час здійснення планових рекультиваційних робіт на післягірничих територіях. За результатами виконання роботи можна зробити такі основні висновки:

1. 3'ясовано, що видобуток бурого вугілля у Східній та Центральній Німеччині повністю змінив ландшафт. Багато територій залишалися без втручання впродовж десятиліть. Тепер більшість територій є рекультивованими, а деякі райони збережені для охорони природи. Фактична інформація про розвиток біорізноманіття під час планування рекультиваційних робіт дає змогу належно врахувати аспекти охорони природи.

2. Виявлено, що різноманітність післягірничих ландшафтів пояснюють формуванням різних видів біотопів. Більшість місцезростань на відвалах є лісопридатними, тому в довготерміновій перспективі очікується домінування лісових насаджень. Сукцесії рослинності можна встановити на підставі водного балансу та властивостей грунту. Площа відкритих територій з типовим видовим складом має тенденцію до зменшення. Цьому можна запобігти такими екологічними методами, як екстенсивне випасання.

3. Встановлено, що невеликі особливі екотопи потрібно зберігати і надавати простір для природного розвитку сукцесії. Доступність таких територій для людей сприяє екологічній освіті, дає змогу набувати нового досвіду і вчитися жити в гармонії з природою.

\section{References}

1. Dunger ,W., \& Voigtlander, K. (2009). Soil fauna (Lumbricidae, Collembola, Diplopoda and Chilopoda) as indicators of soil ecosubsystem development in post-mining sites of Eastern Germany - a review. In: Soil Organisms, 81(1), 1-51.

2. Hildmann, C., \& Schlenstedt, J. (2019). Biodiversität: Arten und Lebensräume in den Bergbaufolgelandschaften des ostdeutschen Braunkohlenbergbaus. In: Rekultivierung und Revitalisierung der Bergbaufolgelandschaften in Polen und Deutschland: Planungs-, Natur und Kulturvoraussetzungen, 99-110.

3. Landeck, I., Kirmer, A., Hildmann, C., \& Schlenstedt, J. (Hg.). (2017). Arten und Lebensräume der Bergbaufolgelandschaften: Chancen der Braunkohlesanierung für den Naturschutz im Osten Deutschlands. Shaker Verlag, Aachen, 560 p.

4. Lorenz, A., \& Landeck, I. (2017). Steckbriefe der Biotop- und Vegetationstypen in der Lausitzer und der Mitteldeutschen Bergbaufolgelandschaft. In: Arten und Lebensräume der Bergbaufolgelandschaften: Chancen der Braunkohlesanierung 
für den Naturschutz im Osten Deutschlands. Shaker Verlag, Aachen, pp. 83-140.

5. Schlenstedt, J. (2017). Braunkohlenbergbau und Bergbausanierung. In: Arten und Lebensräume der Bergbaufolgelandschaften:
Chancen der Braunkohlesanierung für den Naturschutz im Osten Deutschlands. Shaker Verlag, Aachen, pp. 17-26.

U. B. Bashutska

Ukrainian National Forestry University, Lviv, Ukraine

\section{IMPORTANCE OF LANDSCAPE AFTER BROWN COAL MINING IN EASTERN AND CENTRAL GERMANY FOR THE NATURE PROTECTION}

Landscape changes after brown coal mining in East and Central Germany are presented. The natural successions of plant and animal groups in the areas that remained without anthropogenic intervention for decades due to the lag of the rate of reclamation from the rate of coal mining during the GDR are analyzed. Currently, most areas are reclaimed, and some areas are preserved for nature protection. Soil formation processes in extremely warm, dry and acidic edaphotopes do not change for a long time. The situation in wet and flooded habitats is similar. For a long time, they formed stable habitats for plant and animal species that have become rare in cultural landscapes. The dynamics of natural succession is determined by habitat factors. These are water balance (from dry to wet), chemical properties of the soil (acidity, nutrients and phytotoxic substances), as well as the thermal situation of the habitat. A variety of types of habitats and vegetation have been described. Vegetation successions on acidic dump substrates with respect to moisture have been shown based on studies by Landeck et al. The necessity of measures for environmental protection and the danger of violation of its integrity and quality due to mining operations are present. It is important to protect inanimate nature and landscape as a basis for the protection of flora and fauna. The figures show the importance of post-brown coal landscapes for biodiversity and species protection in Germany. The reasons for the success are the diversity of structures, large areas and a relatively low level of anthropogenic interference in former open-cast brown coal mining. These factors have been lost in most of the cultural landscape. When regulating succession, it is necessary to apply approaches as close as possible to natural ones. The population needs to be provided with access to such areas to gain new experiences and a sense of nature.

Keywords: brown coal; post-mining landscapes; reclamation; biodiversity; biotope; natural succession; nature protection. 